\title{
Taxonomic Study of Corynebacterium Group ANF-1 Strains: Proposal of Corynebacterium afermentans sp. nov. Containing the Subspecies $C$. afermentans subsp. afermentans subsp. nov. and $C$. afermentans subsp. lipophilum subsp. nov.
}

\author{
P. RIEGEL, ${ }^{*}$ D. DE BRIEL, G. PRÉVOST, F. JEHL, H. MONTEIL, AND R. MINCK \\ Institut de Bactériologie de la Faculté de Médecine, Université Louis Pasteur, \\ 3 rue Koeberlé, 67000 Strasbourg, France
}

\begin{abstract}
We have determined the cell wall composition, guanine-plus-cytosine $(G+C)$ contents of the DNA, rRNA gene restriction patterns, and the levels of DNA-DNA relatedness of 11 strains identified biochemically as Centers for Disease Control (CDC) Corynebacterium group absolute nonfermenter 1 (Corynebacterium group ANF-1). For seven of these strains, growth is abundant on $5 \%$ sheep blood agar, which differentiates them from the four other strains, whose growth requires a lipid supplement such as Tween 80 . Two of the lipid-requiring strains produced mucoid colonies on $1 \%$ Tween 80 -supplemented sheep blood agar. All strains possess cell wall component type IV, short-chain mycolic acids, and G+C contents of DNA of 66 to 68 mol\% as determined by reverse-phase high-performance liquid chromatography. DNA-relatedness experiments by an 11 nuclease procedure showed that nine of these strains, including two of the lipid-requiring strains, constitute a new genomic species less than $40 \%$ related to Corynebacterium species and other coryneform groups. The lipid-requiring strain T18502 exhibited $98 \%$ DNA relatedness with another lipid-requiring strain, T88593 (difference in thermal denaturation midpoint $\left[\Delta T_{m}\right]=2^{\circ} \mathrm{C}$ ) and 71 to $77 \%$ similarity with the nonlipophilic strains $\left(\Delta T_{m}\right.$ range of from 2 to $\left.5^{\circ} \mathrm{C}\right)$. Conversely, the DNA relatedness between strain LCDC 88199 and the six other nonlipophilic strains ranged from 86 to $100 \%\left(\Delta T_{m}\right.$ range of from 1 to $\left.3^{\circ} \mathrm{C}\right)$ and was only 73 and $76 \%$ with the lipophilic strains $\mathrm{T} 18502$ and $\mathrm{T88593}$, respectively $\left(\Delta T_{m}, 3\right.$ and $\left.4^{\circ} \mathrm{C}\right)$. These results indicated that these two cultural types of bacteria constitute two subspecies within the new genomic species. These subspecies can be identified within the genus Corynebacterium by their phenotypic characteristics and rRNA gene restriction patterns by PvuII and EcoRI endonuclease digestion. The two mucoid strains were not related to other Corynebacterium group ANF-1 strains or Corynebacterium species reference strains. Further studies should allow the determination of the taxonomic status of these mucoid strains. Therefore, we propose a new species, Corynebacterium afermentans sp. nov., which contains two subspecies: $C$. afermentans subsp. afermentans subsp. nov. (type strain, LCDC 88199 = CIP 103499) for nonlipophilic Corynebacterium group ANF-1 strains and $C$. afermentans subsp. lipophilum subsp. nov. (type strain, T18502 = CIP 103500) for two lipid-requiring Corynebacterium group ANF-1 strains.
\end{abstract}

Corynebacterium group absolute nonfermenter 1 (ANF-1) is a bacterial taxon first described in 1981 at the Centers for Disease Control (CDC) (Atlanta, Ga.) in a guide to the identification of medically important gram-positive organisms (12). This unnamed taxon group consists of pleomorphic gram-positive rods which do not produce acid from any sugars and do not possess urease activity. Corynebacterium group ANF-1 differs from Corynebacterium group ANF-3 in its inability to reduce nitrate to nitrite.

Although their natural habitat is not well known, Corynebacterium group ANF-1 strains have been recovered from human clinical specimens, particularly from blood samples and ears (12), but no clinical infections were reported for this taxon group in a review of the clinical aspects of coryneform bacteria (5).

The taxonomic status of Corynebacterium group ANF-1 is not clearly established. The presence of straight-chain or unsaturated cellular fatty acids (2) and the presence of short-chain mycolic acids in some strains (7) were reported to be common features for this and other Corynebacterium species, but no complete chemotaxonomic study and, to

\footnotetext{
* Corresponding author.
}

date, no genomic studies have been performed. Therefore, the purpose of this study was to characterize Corynebacterium group ANF-1 strains by cell wall composition, $\mathrm{G}+\mathrm{C}$ contents of DNA, ribotyping, and DNA-DNA hybridization.

We studied 11 strains which have been identified according to the biochemical classification of the CDC as belonging to Corynebacterium group ANF-1. We compared biochemical properties and determined the genetic relationship of these Corynebacterium group ANF-1 strains with medically relevant Corynebacterium species and related organisms. On the basis of DNA-DNA hybridization and ribotyping results, we propose that two types of Corynebacterium group ANF-1 should be recognized as subspecies of a new species in the genus Corynebacterium for which we propose the name Corynebacterium afermentans.

\section{MATERIALS AND METHODS}

Bacterial strains. The 11 strains identified as Corynebacterium group ANF-1 and the reference strains or clinical isolates of Corynebacterium species and related organisms studied are listed in Table 1.

Corynebacterium group ANF-1 LCDC 88199 was a gift from K. A. Bernard, Laboratory Centre for Disease Control 
TABLE 1. $\mathrm{G}+\mathrm{C}$ contents of and levels of DNA relatedness between strains of $C$. afermentans and other Corynebacterium species or related organisms

\begin{tabular}{|c|c|c|c|}
\hline \multirow[t]{2}{*}{ Source(s) of DNA ${ }^{a}$} & \multirow{2}{*}{$\begin{array}{l}\mathrm{G}+\mathrm{C} \text { content } \\
(\mathrm{mol} \%)^{b}\end{array}$} & \multicolumn{2}{|c|}{$\begin{array}{l}\% \text { Relative binding at } \\
65^{\circ} \mathrm{C} \text { with the following } \\
\text { labeled strain }{ }^{c}:\end{array}$} \\
\hline & & $\begin{array}{l}\text { LCDC } \\
88199^{\mathrm{T}}\end{array}$ & $\mathrm{T} 18502^{\mathrm{T}}$ \\
\hline \multicolumn{4}{|l|}{$\begin{array}{l}\text { C. afermentans subsp. } \\
\text { afermentans }\end{array}$} \\
\hline LCDC $88199^{\mathrm{T}}$ & 66 & $100(0.0)$ & $71(4.0)$ \\
\hline T53478 & 66 & $96(1.0)$ & $73(4.0)$ \\
\hline T94156 & 66 & $100(1.0)$ & $73(3.5)$ \\
\hline $\mathrm{T} 18953$ & 66 & $86(2.0)$ & $76(3.5)$ \\
\hline T8354 & 66 & $98(1.0)$ & $77(5.0)$ \\
\hline T88284 & 66 & $100(2.0)$ & $76(2.0)$ \\
\hline T51462 & 67 & $94(3.0)$ & $76(3.0)$ \\
\hline \multicolumn{4}{|l|}{$\begin{array}{l}\text { C. afermentans subsp. } \\
\text { lipophilum }\end{array}$} \\
\hline $\mathrm{T} 18502^{\mathrm{T}}$ & 68 & $73(4.0)$ & $100(0.0)$ \\
\hline T88593 & $\mathrm{ND}^{d}$ & $76(3.0)$ & $98(2.0)$ \\
\hline C. bovis ATCC $7715^{\mathrm{T}}$ & 74 & 11 & \\
\hline C. cystitidis CIP 69.40 & 61 & 3 & \\
\hline C. diphtheriae NCTC 380 & 55 & 3 & \\
\hline C. glutamicum IAM & 55 & 3 & \\
\hline C. jeikeium CIP 82.51 & 63 & 6 & \\
\hline $\begin{array}{l}\text { C. minutissimum ATCC } \\
23348^{\mathrm{T}}\end{array}$ & 61 & 16 & \\
\hline $\begin{array}{l}\text { C. minutissimum ATCC } \\
23346\end{array}$ & 62 & 8 & \\
\hline C. mycetoides CIP $55.51^{\mathrm{T}}$ & 68 & 24 & 40 \\
\hline C. pilosum ATCC $29592^{\mathrm{T}}$ & 62 & 10 & \\
\hline $\begin{array}{l}\text { C. pseudodiphtheriticum } \\
\text { CIP } 102940\end{array}$ & 55 & 6 & \\
\hline $\begin{array}{l}\text { C. pseudotuberculosis } \\
\text { CIP } 52.97\end{array}$ & 54 & 18 & \\
\hline C. renale CIP 69.37 & 61 & 5 & \\
\hline C. striatum ATCC $6940^{\mathrm{T}}$ & 61 & 10 & \\
\hline C. urealyticum ATCC & 65 & 1 & 12 \\
\hline C. xerosis ATCC $373^{\mathrm{T}}$ & 71 & 5 & \\
\hline \multicolumn{4}{|l|}{$\begin{array}{l}\text { Corynebacterium group } \\
\text { ANF-1 like }\end{array}$} \\
\hline $\mathrm{T} 30014$ & 66 & $30(8.0)$ & $37(9.5)$ \\
\hline $\mathrm{T} 71705$ & ND & 39 & 33 \\
\hline $\begin{array}{l}\text { Corynebacterium group } \\
\text { ANF-3 B77159 }\end{array}$ & 57 & 12 & \\
\hline $\begin{array}{l}\text { Conynebacterium group } \\
\text { F-1 G5911 }\end{array}$ & 63 & 21 & \\
\hline $\begin{array}{l}\text { Corynebacterium group } \\
\text { G-1 F8156 }\end{array}$ & 62 & 13 & \\
\hline $\begin{array}{l}\text { Corynebacterium group } \\
\text { G-2 G795 }\end{array}$ & 62 & 12 & \\
\hline $\begin{array}{l}\text { Corynebacterium group } \\
\text { I-1 F435 }\end{array}$ & 62 & 1 & \\
\hline
\end{tabular}

${ }^{a}$ Corynebacterium groups F-1, G-1, G-2, and I-1 strains were a generous gift from R. E. Weaver, CDC. Corynebacterium group ANF-3 B77159 was isolated in our laboratory.

${ }^{b} \mathrm{G}+\mathrm{C}$ contents are data from this study and reference 16 .

c The values in parentheses are $\Delta T_{m}$ values (in degrees Celsius).

${ }^{d} \mathrm{ND}$, not determined.

(Ottawa, Ontario, Canada). The other 10 Corynebacterium group ANF-1 clinical strains had been isolated from blood cultures (strains T53478, T94156, T18953, T8354, T51462, T18502, T88593, T30014, T88284, and T71705). These clinical isolates were from patients hospitalized in Strasbourg (France). The following strains of recognized Corynebacte- rium species were obtained from the Collection of the Institut Pasteur (CIP), the American Type Culture Collection (ATCC), the National Collection of Type Cultures (NCTC), and the Institute of Applied Microbiology (IAM): C. bovis NCTC 3324 (ATCC 7715, type strain), C. cystitidis CIP 69.40, C. diphtheriae CIP A102 (Park-Williams 8), C. glutamicum IAM 12435 (ATCC 13022, type strain), $C$. jeikeium CIP 82.51, C. minutissimum NCTC 10288 (ATCC 23348, type strain) and ATCC 23346, C. mycetoides CIP 55.51 (ATCC 21134, type strain), C. pilosum ATCC 29592 (type strain), C. pseudodiphtheriticum CIP 102940, C. pseudotuberculosis bv. equi CIP 52.97, C. renale CIP 69.37, C. striatum CIP 81.15 (ATCC 6940, type strain), C. urealyticum ATCC 43042 (type strain), and C. xerosis ATCC 373 (type strain). The reference strains which are not the type strains of the named species were verified to possess the same biochemical characteristics as and $\mathrm{G}+\mathrm{C} \%$ contents of DNA similar to those of those reported for the type strains $(4,14)$. The strains of Corynebacterium groups F-1 (G5911), G-1 (F8156), G-2 (G795), and I-1 (F435) were a generous gift from R. E. Weaver, CDC. The Corynebacterium group ANF-3 strain B77159 was isolated in our laboratory from a human respiratory tract specimen and identified according to the method of Hollis and Weaver (12).

Growth conditions and biochemical tests. Bacteria were grown aerobically at $37^{\circ} \mathrm{C}$ on $5 \%$ sheep blood agar (Trypticase soy agar, Biomérieux, Marcy l'Etoile, France) and on $5 \%$ sheep blood agar supplemented with $1 \%$ (vol/vol) Tween 80 (polyoxyethylene sorbitan mono-oleate) (Merck, Darmstadt, Germany).

The procedures used for the determination of biochemical characteristics have been described elsewhere (16). The isolates were identified according to the method of Hollis and Weaver (12). Fermentation tests were verified with API Coryne systems (Biomérieux). Enzymatic activities were examined by the API Zym system according to the manufacturer's instructions (Biomérieux). Assimilation tests were performed by the API $20 \mathrm{NE}$ system. For acetate, propionate, and lactate assimilation tests, a mineral base (15) was supplemented with $2 \mathrm{~g}$ of these components per liter. Antimicrobial susceptibilities were determined by the Bauer diffusion method with 5\% sheep blood agar and an inoculum of approximately $10^{5} \mathrm{CFU} / \mathrm{ml}(1)$.

Cell wall analysis. Samples for amino acid and sugar determinations were prepared and separated by thin-layer chromatography, and the components were identified as described previously (20). Reverse-phase high-performance liquid chromatography was performed for the determination of mycolic acids. Saponification, derivatization conditions, and comparison of mycolic acid patterns were carried out by following a previously published procedure (7).

DNA base composition. Cultures were grown for $48 \mathrm{~h}$ on Mueller-Hinton agar (Oxoid, Basingstoke, England) supplemented with $1 \%$ (vol/vol) Tween 80 . Cells were harvested and resuspended in $20 \mathrm{ml}$ of $0.2 \mathrm{M}$ sucrose- $0.05 \mathrm{M}$ Tris- $\mathrm{HCl}$ (pH 8.0). Incubation at $37^{\circ} \mathrm{C}$ for $2 \mathrm{~h}$ in the presence of $2.5 \mathrm{mg}$ of lysozyme per $\mathrm{ml}$ was followed by the addition of $10 \mathrm{mg}$ of sodium dodecyl sulfate (SDS) at $55^{\circ} \mathrm{C}$ for $2 \mathrm{~h}$. DNA was then extracted and purified by the method of Brenner et al. (3). After being purified on cesium chloride gradients, the DNA for $\mathrm{G}+\mathrm{C}$ content determination was hydrolyzed with DNase $I$ and nuclease P1 (8) and the moles percent $G+C$ was determined by reverse-phase high-performance liquid chromatography of the deoxynucleotides as described previously (16).

DNA-DNA hybridization. DNAs from Corynebacterium 
group ANF-1 strains LCDC 88199 and T18502 were labeled by nick translation with $\left[{ }^{3} \mathrm{H}\right] \mathrm{dCTP}$ (Amersham International, Amersham, United Kingdom) with a commercial kit (Boehringer GmbH, Mannheim, Germany).

DNA-DNA hybridization was carried out at $65^{\circ} \mathrm{C}$ for $16 \mathrm{~h}$ in $0.42 \mathrm{M} \mathrm{NaCl}$ by the $\mathrm{S} 1$ nuclease-trichloroacetic method (11). The denaturation temperature $\left(T_{m}\right)$ at which $50 \%$ of the reassociated DNA becomes hydrolyzable by $\mathrm{S} 1$ nuclease was determined in $0.2 \mathrm{M} \mathrm{NaCl}$ by the method of Crosa et al. (6). $\Delta T_{m}$ is the difference between the $T_{m}$ of a homoduplex (in a homologous reaction) and the $T_{m}$ of heteroduplexes (in heterologous reactions).

Ribotyping. Ribotyping was performed as described by Grimont and Grimont (9). DNA was digested for $4 \mathrm{~h}$ at $37^{\circ} \mathrm{C}$ with $E c o$ RI or PvuII restriction endonuclease. DNA fragments were separated overnight by agarose gel electrophoresis $(2 \mathrm{~V} / \mathrm{cm})$ in $0.5 \times$ TEB $(10 \times$ TEB is $0.89 \mathrm{M}$ Tris, $0.89 \mathrm{M}$ boric acid, and $25 \mathrm{mM}$ EDTA $\mathrm{Na}_{2}[\mathrm{pH} 8.3]$ ) and then transferred onto an Immobilon $\mathbf{P}$ membrane (Millipore) with $0.5 \mathrm{M} \mathrm{NaOH}$ by the method of Southern (19). Prehybridization was performed in $6 \times \operatorname{SSPE}(1 \times \mathrm{SSPE}$ is $0.18 \mathrm{M} \mathrm{NaCl}$, $10 \mathrm{mM}$ sodium phosphate, and $1 \mathrm{mM}$ EDTA [pH 7.7]) (17), $5 \times$ Denhardt's solution (17), and $0.1 \%(\mathrm{wt} / \mathrm{vol}) \mathrm{SDS}$ at $50^{\circ} \mathrm{C}$ for 2 h. Escherichia coli $16 \mathrm{~S}$ and $23 \mathrm{~S}$ rRNAs, previously dephosphorylated with calf intestine alkaline phosphatase (Boehringer), were $5^{\prime}$ labeled with $\left[\gamma^{-}{ }^{32} \mathrm{P}\right] \mathrm{ATP}$ by T4 polynucleotide kinase. Hybridization between Conynebacterium DNA and $E$. coli rRNA was performed overnight at $60^{\circ} \mathrm{C}$ in the prehybridization solution supplemented with $2.5 \times 10^{6}$ $\mathrm{dpm}(50 \mathrm{ng})$ of $5^{\prime}-{ }^{32} \mathrm{P}$-labeled rRNA per $20 \mathrm{ml}$ and per membrane. After hybridization, the filters were washed twice in $0.1 \times \mathrm{SSPE}-0.1 \%$ (wt/vol) SDS at $37^{\circ} \mathrm{C}$ for $15 \mathrm{~min}$. Hybridized bands were visualized by autoradiography at $-70^{\circ} \mathrm{C}$ with intensifying screens for a maximum of $24 \mathrm{~h}$.

\section{RESULTS}

Phenotypic characterization. The 11 strains were identified as belonging to Corynebacterium group ANF-1 by Hollis and Weaver's identification scheme (12). These strains do not produce acid from any sugars or nitrite from nitrate, and they do not possess urease activity. Four of these strains (T18502, T88593, T30014, and T71705) showed a lipid requirement, such as Tween 80 , which has not been described for this taxon group. Tween 80 is the most commonly used component in studies characterizing lipophilic or lipid-dependent strains. The term "lipid requiring" is appropriate for the four strains of Corynebacterium group ANF-1 with which no visible growth occurs in brain heart infusion broth in $48 \mathrm{~h}$ and with which only very small colonies appear after several days on sheep blood agar alone. In contrast, on $1 \%$ Tween 80 -supplemented sheep blood agar, large colonies are observed in $48 \mathrm{~h}$. Furthermore, we observed that two of these nonfermenter lipid-requiring strains (T30014 and T71705) developed mucoid colonies on the Tween 80-supplemented medium. The nonlipophilic Corynebacterium group ANF-1 strains show widespread growth on either sheep blood agar or $1 \%$ Tween 80 -supplemented sheep blood agar (Fig. 1).

By a high-performance liquid chromatography method which has been validated as a rapid and reliable method for the identification of coryneform bacteria (7), the esters of mycolic acids from the seven nonlipophilic Corynebacterium group ANF-1 strains and two of the lipid-requiring strains, T18502 and T88593, exhibited characteristic patterns which differentiated these strains from the mucoid Corynebacte-
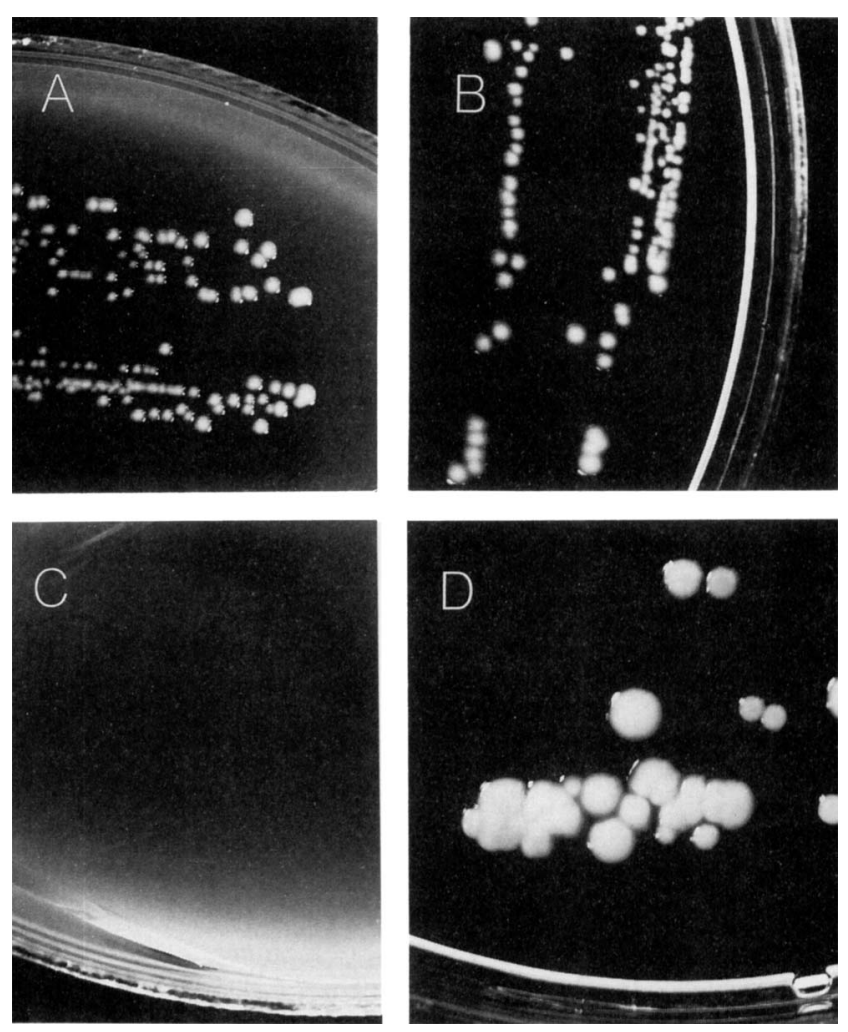

FIG. 1. Growth of Conynebacterium group ANF-1 strains on 5\% sheep blood agar (A and $\mathrm{C}$ ) and 1\% Tween 80-supplemented sheep blood agar (B and D) for $72 \mathrm{~h}$ at $37^{\circ} \mathrm{C}$. (A and B) Nonlipophilic strain LCDC 88199

rium group ANF-1 strains and the other Corynebacterium species.

Cell wall components and DNA base composition. The cell walls of the 11 strains identified as Corynebacterium group ANF-1 were found to contain cell wall component type IV (meso-diaminopimelic acid, arabinose, and galactose) and mycolic acids of short chain lengths $\left(C_{26}\right.$ to $\left.C_{36}\right)$. These results support the assignment of these strains to the genus Corynebacterium (4). The $\mathrm{G}+\mathrm{C}$ contents of all strains studied are listed in Table 1 . The values for nonlipophilic and Tween-requiring Corynebacterium group ANF-1 strains show a tight cluster ( 66 to $68 \mathrm{~mol} \%$ ) and are similar to those for C. urealyticum and C. mycetoides. The other Corynebacterium species and related organisms, notably Corynebacterium group ANF-3, showed quite different values.

DNA-DNA hybridization. As shown in Table 1, DNADNA hybridization of DNAs from Corynebacterium group ANF-1 strains with labeled DNAs from strains LCDC $88199^{\mathrm{T}}$ and $\mathrm{T} 18502^{\mathrm{T}}$ of the two proposed subspecies, respectively, revealed the division of group ANF-1 into two genomic groups. The DNA relatedness between strain LCDC $88199^{\mathrm{T}}$ and the other six nonlipophilic Corynebacterium group ANF-1 strains ranged from 86 to $100 \%$, with a difference in melting temperature $\Delta T_{m}$ range of from 1 to $3^{\circ} \mathrm{C}$ $\left(\right.$ mean $\left.=1.7^{\circ} \mathrm{C}\right)$. The DNA relatedness between strain LCDC $88199^{\mathrm{T}}$ and two of the Tween-requiring strains, $\mathrm{T} 18502^{\mathrm{T}}$ and T88593, was 73 and $76 \%$, respectively, and the $\Delta T_{m}$ was 3 and $4^{\circ} \mathrm{C}$, respectively. Conversely, strain $\mathrm{T} 18502^{\mathrm{T}}$ exhibited 98\% DNA relatedness with another Tween-requiring strain, T88593 $\left(\Delta T_{m}=2^{\circ} \mathrm{C}\right)$, and 71 to $77 \%$ similarity with typical 


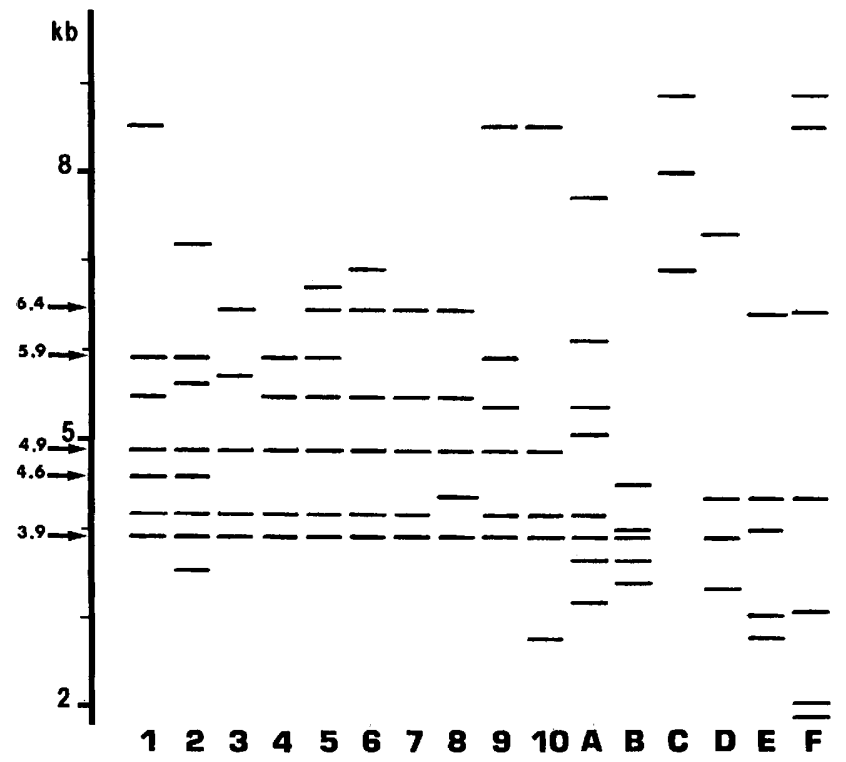

FIG. 2. Schematic patterns of the different $P v u I I$ ribotypes according to the length of each DNA fragment (in kilobases). Lanes: 1 and 2, lipid-requiring Corynebacterium group ANF-1 strains T18502 ${ }^{\mathrm{T}}$ and T88593, respectively; 3 to 9, nonlipophilic Corynebacterium group ANF-1 strains (lane 3, LCDC $88199^{\mathrm{T}}$ ); 10 , Corynebacterium group ANF-1-like T30014; A, $C$. diphtheriae NCTC 380; B, C. jeikeium CIP 82.51; C, C. urealyticum ATCC $43042^{\mathrm{T}} ; \mathrm{D}, C$. xerosis ATCC $373^{\mathrm{T}}$; E, C. pseudodiphtheriticum CIP 102940; F, C. striatum ATCC $6940^{\mathrm{T}}$. The arrows indicate the bands differentiating the species and subspecies.

strains belonging to Corynebacterium group ANF-1 $\left(\Delta T_{m}\right.$ range of from 2 to $5^{\circ} \mathrm{C}$; mean $=3.6^{\circ} \mathrm{C}$ ).

Corynebacterium species and mycolic acid-containing coryneform groups were 1 to $24 \%$ related to strain LCDC $88199^{\mathrm{T}}$ at $65^{\circ} \mathrm{C}$, and Corynebacterium species with $\mathrm{G}+\mathrm{C}$ contents near $66 \%$ were 12 to $40 \%$ related to Tweenrequiring Corynebacterium group ANF-1 strain $\mathrm{T} 18502^{\mathrm{T}}$. The mucoid Corynebacterium group ANF-1 strains T30014 and T71705 exhibited 30 to $39 \%$ hybridization with DNA from either LCDC $88199^{\mathrm{T}}$ or T18502 ${ }^{\mathrm{T}}$. Further studies should allow the determination of the taxonomic status of these mucoid, lipid-requiring strains.

Ribotyping. In order to further characterize the Corynebacterium group ANF-1 strains, we determined the rRNA gene restriction patterns of these strains and those of some medically important Corynebacterium species. After PvuII cleavage of DNA, heterogeneous but closely related patterns were observed for the seven nonlipophilic strains and for the two lipid-requiring strains $\mathrm{T} 18502^{\mathrm{T}}$ and $\mathrm{T} 88593$.

The DNA band profiles of these nine strains for this DNA restriction hydrolysis showed the presence of at least three common bands among the four bands of approximately 3.9 , $4.9,5.9$, and $6.4 \mathrm{~kb}$, which differentiate between the mucoid Corynebacterium group ANF-1 strain T30014 (two bands) and the other Corynebacterium species (one or no bands) (Fig. 2). The profiles of the two Tween-requiring strains $\mathrm{T} 18502^{\mathrm{T}}$ and $\mathrm{T} 88593$ showed an additional band of $4.6 \mathrm{~kb}$ that was not found in the other strains. The two mucoid Corynebacterium group ANF-1 strains T30014 and T71705 were clearly differentiated from the other Corynebacterium group ANF-1 strains by EcoRI endonuclease digestion of total DNAs (Fig. 3).

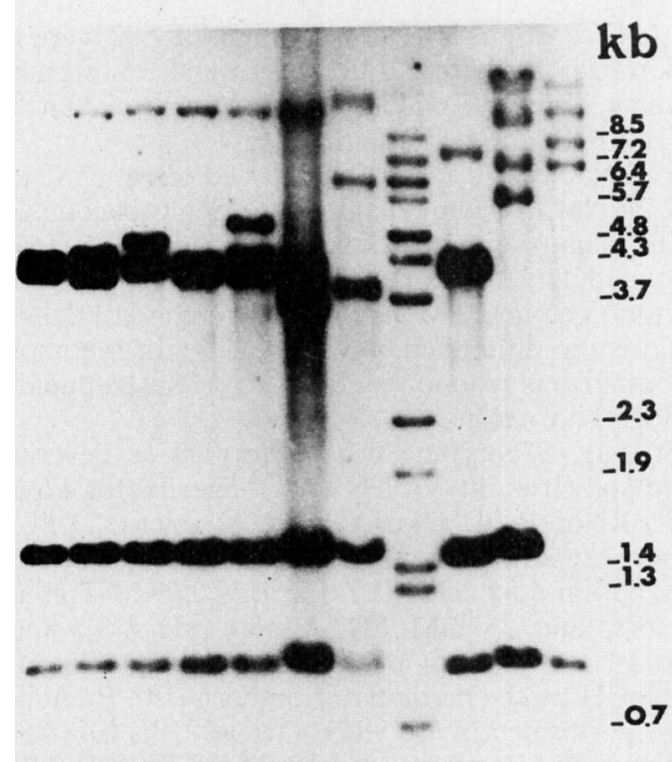

1234567891011

FIG. 3. rRNA gene restriction patterns after cleavage by EcoRI. The lengths of DNA fragments (in kilobases) were obtained by comparison with $5^{\prime}-{ }^{32} \mathrm{P}$-labeled BstEII fragments of lambda DNA (lane 8). Lanes: 1 to 6, nonlipophilic Corynebacterium group ANF-1 strains (lane 1, LCDC $88199^{\mathrm{T}}$ ); 7 and 9, lipid-requiring Corynebacterium group ANF-1 strains T18502 ${ }^{\mathrm{T}}$ and T88593, respectively; 10 and 11, mucoid Corynebacterium group ANF-1 strains.

These results agree with DNA-DNA hybridization values and indicate that these two digestions with restriction enzymes may serve as a discriminatory genomic marker for studying rRNA genes of the Corynebacterium group ANF-1 strains within the genus Corynebacterium.

\section{DISCUSSION}

A species is considered to include strains with $70 \%$ or greater DNA-DNA relatedness and with $5^{\circ} \mathrm{C}$ or less $\Delta T_{m}$ (21). According to this generally accepted criterion defining a genomic species, the seven strains of nonlipophilic Corynebacterium group ANF-1 and the Tween-requiring strains $\mathrm{T} 18502^{\mathrm{T}}$ and $\mathrm{T} 88593$ constitute a new genomic species in the genus Corynebacterium for which we propose the name $C$. afermentans.

Thus, this chemotaxonomic and genomic study has confirmed that Corynebacterium group ANF-1, as described by Hollis and Weaver (12), is a distinct taxon group in the genus Corynebacterium. Moreover, we have found that lipidrequiring strains should be included in this group. In the genus Corynebacterium, a variant intermedius is described for lipophilic strains of $C$. diphtheriae, and Smith considered some lipid-requiring diphtheroids to be identical to $C$. xerosis on the basis of biochemical tests (18). Here, we have found that a single genomic group can contain both lipophilic and nonlipophilic strains.

The reassociation values and $\Delta T_{m}$ values indicate significant sequence divergence in this genomic species between the typical strains and two of the Tween-requiring strains. On the basis of frequency of distribution of divergence values, Grimont found that a $\Delta T_{m}$ of approximately $3^{\circ} \mathrm{C}$ corresponds to divergence values occurring among different 
TABLE 2. Characteristics used for differentiation of two subspecies of $C$. afermentans from medically relevant Corynebacterium species $^{a}$

\begin{tabular}{|c|c|c|c|c|c|c|}
\hline \multirow{3}{*}{ Species } & \multicolumn{6}{|c|}{ Value $^{b}$ for the following characteristic: } \\
\hline & \multirow{2}{*}{ Urease } & \multirow{2}{*}{$\begin{array}{l}\text { Nitrate } \\
\text { reductase }\end{array}$} & \multirow{2}{*}{$\begin{array}{l}\text { Lipid } \\
\text { requirement }\end{array}$} & \multicolumn{3}{|c|}{ Acid from: } \\
\hline & & & & Glucose & Sucrose & Maltose \\
\hline $\begin{array}{l}\text { C. afermentans subsp. } \\
\text { afermentans }\end{array}$ & - & - & - & - & - & - \\
\hline $\begin{array}{l}\text { C. afermentans subsp. } \\
\text { lipophilum }\end{array}$ & - & - & + & - & - & - \\
\hline C. diphtheriae & - & + & d & + & - & + \\
\hline C. bovis & - & - & + & + & - & - \\
\hline C. jeikeium & - & - & + & + & - & $\mathrm{d}$ \\
\hline C. minutissimum & - & - & - & + & $\mathrm{d}$ & + \\
\hline C. pseudodiphtheriticum & + & + & - & - & - & - \\
\hline C. pseudotuberculosis & + & d & + & + & d & + \\
\hline C. renale & + & - & - & + & - & $\mathrm{d}$ \\
\hline C. striatum & - & + & - & + & + & - \\
\hline C. urealyticum & + & - & + & - & - & - \\
\hline C. xerosis & - & + & - & + & + & + \\
\hline
\end{tabular}

${ }^{a}$ Data are from references 4 and 12 and our observations.

$b+, 90 \%$ or more positive strains;,$- 10 \%$ or less positive strains; $d, 11$ to $89 \%$ of positive strains.

subspecies within a species (10). Our results show a $3.6^{\circ} \mathrm{C}$ $\Delta T_{m}$ with levels of DNA-DNA relatedness of 70 to $80 \%$ between nonlipophilic strains and the Tween-requiring strains. Thus, we believe that these DNA-DNA hybridization and $\Delta T_{m}$ values provide sufficient genomic evidence to recognize these two closely related genomic groups at the subspecies level in this new species.

C. afermentans can be distinguished from other Corynebacterium species by its biochemical characteristics (Table 2). However, some difficulties in identifying coryneform isolates at the genus level have been reported (5). Thus, cell wall component analysis, including mycolic acid determination, may provide the identification at the genus level for coryneform strains which do not produce acid from sugars.

On the basis of culture, biochemical, and nucleic acid characteristics, we propose a new species, $C$. afermentans sp. nov., which contains two subspecies: $C$. afermentans subsp. afermentans subsp. nov., formerly nonlipophilic Corynebacterium group ANF-1 strains, and C. afermentans subsp. lipophilum subsp. nov., formerly lipid-requiring Corynebacterium group ANF-1 strains.

C. afermentans subsp. afermentans sp. nov. $C$. afermentans (a.fer.men'tans. Gr. pref. $a$, not; L. part. adj. fermentans, leavening; M.L. adj. afermentans, nonfermenting carbohydrates).

This description is based on observations of the authors and descriptions of the literature of Corynebacterium group ANF-1 strains $(2,4,7,12,13)$.

The bacteria are gram-positive, irregular rods or coccobacilli that sometimes contain metachromatic granules. All are nonmotile and nonspore forming and are arranged in typical V-shaped forms or palisades. They are not acid fast, and no rod-coccus cycle is present. They are catalase positive and oxidase negative. They exhibit good growth under aerobic conditions and very slight growth under anaerobic conditions. Nonhemolytic colonies (1 to $2 \mathrm{~mm}$ in diameter) are grayish-white and smooth after $24 \mathrm{~h}$ at $37^{\circ} \mathrm{C}$ on fresh sheep blood agar. On $1 \%$ Tween 80-supplemented medium, bright colonies ( $2 \mathrm{~mm}$ in diameter) are beige, and Tween 80 esterase activity is detected. Acid is not produced from D-glucose, glycogen, lactose, sucrose, ribose, D-xylose, D-mannose, D-galactose, trehalose, and D-mannitol or on triple sugar iron agar. Tyrosine, gelatin, DNA, starch, and urea are not degraded. Esculin is not hydrolyzed. The methyl red test is negative, and acetoin, indole, and $\mathrm{H}_{2} \mathrm{~S}$ (on triple sugar iron agar) are not produced. Hydrolysis of hippurate is variable. Growth is visible in $6.5 \% \mathrm{NaCl}$. Alkaline phosphatase, esterase, lipase, and acid phosphatase are produced. $\alpha$-Galactosidase, $\beta$-galactosidase, $\alpha$-glucuronidase, $\alpha$-glucosidase, and $\beta$-glucosidase are not produced. Cells utilize acetate and lactate. Propionate, D-glucose, L-arabinose, D-mannose, D-mannitol, $N$-acetyl-glucosamine, maltose, gluconate, caprate, adipate, malate, citrate, and phenyl acetate are not utilized. The strains are susceptible to ampicillin, mezlocillin, piperacillin, ticarcillin, cephalotin, cefotaxime, gentamicin, netilmicin, amikacin, norfloxacin, ciprofloxacin, vancomycin, teicoplanin, rifampicin, pristinamycin, tetracycline, and fusidic acid, and some strains are susceptible to erythromycin, virginiamycin, and nitrofurantoin. All strains are resistant to fosfomycin.

The cell wall contains meso-diaminopimelic acid, arabinose, and galactose. Straight-chain saturated fatty acids are mainly palmitic and stearic acids. Branched saturated fatty acids are heptadecanoic acid and pentadecanoic acid. Straight-chain unsaturated fatty acids are mainly oleic acid and linoleic acid. The predominant types of mycolic acids are $\mathrm{C}_{30: 0}, \mathrm{C}_{30: 1}, \mathrm{C}_{32: 1}, \mathrm{C}_{33: 1}, \mathrm{C}_{34: 2}$, and $\mathrm{C}_{36: 2}$. The DNA base composition is 66 to $67 \mathrm{~mol} \% \mathrm{G}+\mathrm{C}$. C. afermentans subsp. afermentans strains were isolated from human clinical specimens such as blood samples, skin, and ears, but no pathogenic relationships were reported.

The type strain is LCDC 88199 (= CIP 103499). It was isolated in Canada from a human blood culture. Strain CIP $103499^{\mathrm{T}}$ has all of the above properties for the species. Hippurate is not hydrolyzed. The $\mathrm{G}+\mathrm{C}$ content of its DNA is $66 \mathrm{~mol} \%$.

C. afermentans subsp. lipophilum subsp. nov. The biochemical characteristics of $C$. afermentans subsp. lipophilum (li.po'phi.lum. Gr. n. lipos, animal fat; Gr. adj. philos, loving; M.L. adj. lipophilus, fat loving) are similar to those of $C$. afermentans subsp. afermentans except that growth is not visible in brain heart infusion broth and very small colonies appear after $48 \mathrm{~h}$ on sheep blood agar, but on $1 \%$ Tween 80-supplemented sheep blood agar, beige colonies 
are large ( $2 \mathrm{~mm}$ in diameter) and without a mucoid consistency. Bacteria are pleomorphic gram-positive, nonsporeforming rods or coccobacilli that sometimes contain metachromatic granules. They are nonmotile and arranged in palisades and $\mathrm{V}$ shapes. They are not acid fast, and no rod-coccus cycle is present. They are catalase positive and oxidase negative. Acid is not produced from D-glucose, glycogen, lactose, sucrose, ribose, D-xylose, D-mannose, D-galactose, trehalose, and D-mannitol or on triple sugar iron. Tyrosine, gelatin, DNA, and urea are not degraded. Esculin is not hydrolyzed. The methyl red test is negative, and acetoin, indole, and $\mathrm{H}_{2} \mathrm{~S}$ (on triple sugar iron agar) are not produced. Hippurate is not hydrolyzed. Alkaline phosphatase, esterase, lipase, and acid phosphatase are produced. $\alpha$-Galactosidase, $\beta$-galactosidase, $\alpha$-glucuronidase, $\alpha$-glucosidase, and $\beta$-glucosidase are not produced. Cells utilize acetate and lactate. Propionate, D-glucose, L-arabinose, D-mannose, D-mannitol, $N$-acetyl-glucosamine, maltose, gluconate, caprate, adipate, malate, citrate, and phenyl acetate are not utilized. The strains are susceptible to ampicillin, mezlocillin, piperacillin, ticarcillin, cephalotin, cefotaxime, gentamicin, netilmicin, amikacin, norfloxacin, ciprofloxacin, vancomycin, teicoplanin, rifampicin, pristinamycin, tetracycline, and fusidic acid, and some strains are susceptible to erythromycin. All strains are resistant to fosfomycin.

The cell wall contains meso-diaminopimelic acid, arabinose, galactose, and corynomycolic acids. Straight-chain saturated fatty acids are mainly palmitic and stearic acids. Branched saturated fatty acids are heptadecanoic acid. Straight-chain unsaturated fatty acids are mainly oleic acid, linoleic acid, and arachidonic acid. The DNA base composition is $68 \mathrm{~mol} \% \mathrm{G}+\mathrm{C}$. Bacteria were isolated from human blood cultures.

The type strain is strain T18502 (= CIP 103500). It was isolated at Strasbourg (France) from a human blood culture. Strain CIP $103500^{\mathrm{T}}$ has the characteristics described for the species.

\section{ACKNOWLEDGMENTS}

We thank B. Muller and M. Pelegrin for helpful assistance, G. A. Green for critical reading of the manuscript, and A. von Graevenitz, Department of Medical Microbiology, University of Zürich, Switzerland, for help with the analysis of cellular fatty acids of lipophilic bacterial strains. In addition, we gratefully acknowledge P. E. Ewan, LCDC, and R. E. Weaver, CDC, for kindly providing strains of unnamed CDC taxon groups.

\section{REFERENCES}

1. Bauer, A. W., W. M. M. Kirby, J. C. Sherris, and M. Turck. 1966. Antibiotic susceptibility testing by a standardized single disk method. Am. J. Clin. Pathol. 45:493-496.

2. Bernard, K. A., M. Bellefeuille, and P. E. Ewan. 1991. Cellular fatty acid composition as an adjunct to the identification of asporogenous, aerobic gram-positive rods. J. Clin. Microbiol. 29:83-89.

3. Brenner, D. J., A. C. McWhorter, J. K. Leete Knutson, and A. G. Steigerwalt. 1982. Escherichia vulneris: a new species of Enterobacteriaceae associated with human wounds. J. Clin. Microbiol. 15:1113-1140.
4. Collins, M., and C. Cummins. 1985. Genus Corynebacterium, Lehmann and Neumann $1896,350^{\mathrm{AL}}$, p. 1266-1276. In P. H. A. Sneath, N. S. Mair, M. E. Sharpe, and J. G. Holt (ed.), Bergey's manual of systematic bacteriology, vol. 2. The Williams \& Wilkins Co., Baltimore.

5. Coyle, M. B., and B. J. Lipsky. 1990. Coryneform bacteria in infectious diseases: clinical and laboratory aspects. Clin. Microbiol. Rev. 3:227-246.

6. Crosa, J. H., D. J. Brenner, and S. Falkow. 1973. Use of a single-strand specific nuclease for analysis of bacterial and plasmid deoxyribonucleic acid homo- and heteroduplexes. J. Bacteriol. 115:904-911.

7. De Briel, D., F. Couderc, P. Riegel, F. Jehl, and R. Minck. 1992. High-performance liquid chromatography of corynomycolic acids as a tool in identification of Corynebacterium species and related organisms. J. Clin. Microbiol. 30:1407-1417.

8. Gehrke, C. W., R. A. McCune, M. A. Gama-Sosa, M. Erlich, and K. C. Kuo. 1984. Quantitative reversed-phase high performance liquid chromatography of major and modified nucleoside in DNA. J. Chromatogr. 301:199-219.

9. Grimont, F., and P. A. D. Grimont. 1986. Ribosomal nucleic acid gene restriction patterns as potential taxonomic tools. Ann. Inst. Pasteur Microbiol. 137B:165-175.

10. Grimont, P. A. D. 1988. Use of DNA reassociation in bacterial classification. Can. J. Microbiol. 34:541-546.

11. Grimont, P. A. D., M. Y. Popoff, F. Grimont, C. Coynault, and M. Lemelin. 1980. Reproducibility and correlation study of three deoxyribonucleic acid hybridization procedures. Curr. Microbiol. 4:325-330.

12. Hollis, D. G., and R. E. Weaver. 1981. Gram-positive organisms: a guide to identification. Centers for Disease Control, Atlanta, $\mathrm{Ga}$.

13. Krech, T., and D. G. Hollis. 1991. Corynebacterium and related organisms, p. 277-286. In A. Balows, W. J. Hansler, Jr., K. L. Herrmann, H. D. Isenberg, and H. J. Shadomy (ed.), Manual of clinical microbiology, 5th ed. American Society for Microbiology, Washington, D.C.

14. Pitcher, D. G. 1988. Deoxyribonucleic acid base composition of Corynebacterium diphtheriae and other corynebacteria with cell wall type IV. FEMS Microbiol. Lett. 16:291-295.

15. Rasoamananjara, D., B. Korosec, and H. Monteil. 1987. Classification and identification of Flavobacterium species by carbon source utilization. J. Clin. Microbiol. 25:1285-1290.

16. Riegel, P., P. A. D. Grimont, D. De Briel, E. Ageron, F. Jehl, M. Pelegrin, H. Monteil, and R. Minck. 1992. Corynebacterium group D-2 ("Corynebacterium urealyticum") constitutes a new genomic species. Res. Microbiol. 143:307-313.

17. Sambrook, J., E. F. Fritsch, and T. Maniatis. 1989. Molecular cloning: a laboratory manual, 2nd ed. Cold Spring Harbor Laboratory, Cold Spring Harbor, N.Y.

18. Smith, R. F. 1969. Characterization of human cutaneous lipophilic diphtheroids. J. Gen. Microbiol. 55:433-443.

19. Southern, E. M. 1975. Detection of specific sequences among DNA fragments separated by gel electrophoresis. J. Mol. Biol. 98:503-517.

20. Staneck, J. L., and G. D. Roberts. 1974. Simplified approach to identification of aerobic actinomycetes by thin-layer chromatography. Appl. Microbiol. 28:226-231.

21. Wayne, L. G., D. J. Brenner, R. R. Colwell, P. A. D. Grimont, O. Kandler, M. J. Krichevsky, L. H. Moore, W. E. C. Moore, R. G. E. Murray, E. Stackebrandt, M. P. Starr, and L. G. Trüper. 1987. Report of the ad hoc committee on reconciliation of approaches to bacterial systematics. Int. J. Syst. Bacteriol. 37:463-464. 